\title{
PREDIKSI DEBIT ALIRAN MASUK KE TELAGA MENJER MENGGUNAKAN PERSAMAAN NERACA AIR DAN PEMODELAN HEC-HMS
}

\section{INFLOWS PREDICTION TOTHE MENJER LAKE USING HEC-HMS MODEL AND WATER BALANCE APPROACH}

\author{
Hiro Agung Pratama1), Jazaul Ikhsan ${ }^{2}{ }^{*}$, Apip $^{3)}$ \\ 1,2)Universitas Muhammadiyah Yogyakarta \\ Jl. Brawijaya, Geblagan, Tamantirto, Kasihan, Bantul, Yogyakarta, Indonesia 55183 \\ 3)Lembaga Ilmu Pengetahuan Indonesia \\ Jl. Raya Jakarta-Bogor Km 46, Bogor, Indonesia 16911 \\ *Correspondence email: jazaul.ikhsan@umy.ac.id \\ Diterima: 27 Maret 2021; Direvisi: 05 April 2021; Disetujui: 07 Desember 2021
}

\begin{abstract}
The Menjer lake is the main source for Hydroelectric Power Plant of the PLTA Garung. Information about the water balance and the potential of existing water resources in the Menjer Catchment Area (DTA) is needed to obtain an efficient operating pattern, the sustainability of the Garung hydropower plant, and good management of the Menjer Lake. The purpose of this study was to estimate the inflow of three main rivers in the Menjer catchment area using HEC-HMS hydrological and water balance approach. Simulated results of the HEC-HMS model shows that the average of total the inflows of three main rivers to the Menjer lake in 2017, 2018 and 2019 during rainy season are $0.954 \mathrm{~m}^{3} / \mathrm{s}, 0.944 \mathrm{~m}^{3} / \mathrm{s}$, and $1.017 \mathrm{~m}^{3} / \mathrm{s}$, and during dry season are $0.820 \mathrm{~m}^{3} / \mathrm{s}, 0.783 \mathrm{~m}^{3} / \mathrm{s}$, and $0.80 \mathrm{~m}^{3} / \mathrm{s}$, respectively. While the prediction results of the discharge with the equation of the water balance shows that the average of total river inflows to the Menjer lake during rainy season is 2017 is $1.628 \mathrm{~m}^{3} / \mathrm{s}$, in 2018 it is $1.579 \mathrm{~m}^{3} / \mathrm{s}$, and in 2019 it is $3.296 \mathrm{~m}^{3} / \mathrm{s}$ and during dry season is $1.893 \mathrm{~m}^{3} / \mathrm{s}$ in $2017,1.176 \mathrm{~m}^{3} / \mathrm{s}$ tahun 2018, and $1.893 \mathrm{~m}^{3} / \mathrm{s}$ in 2019. These results indicate that the results of discharge modeling with HEC-HMS are smaller than those predicted by the water balance equation. The study concluded that HEC-HMS could be used to predict daily inflows. However, further calibration and validation need to be carried out by recommending installing a river flow monitoring station at each river outlet.
\end{abstract}

Keywords: water balance HEC-HMS, inflow prediction

ABSTRAK

Telaga Menjer adalah sumber utama dan tampungan air untuk PLTA Garung. Informasi tentang neraca air dan potensi sumber daya air yang ada pada Daerah Tangkapan Air (DTA) Menjer dibutuhkan untuk mendapatkan pola operasi yang efisien, keberlanjutan PLTA Garung dan tata kelola Telaga Menjer yang baik. Penelitian ini bertujuan untuk memprediksi debit dari tiga sungai utama di DTA Menjer dengan pemodelan HEC-HMS dan dengan persamaan neraca air. Dari hasil perhitungan dengan model HEC-HMS, debit rerata pada musim penghujan diperoleh nilai pada tahun 2017 sebesar 0,954 $\mathrm{m}^{3} / \mathrm{s}$, pada tahun 2018 0,944 $\mathrm{m}^{3} / \mathrm{s}$ dan pada tahun $20191,017 \mathrm{~m}^{3} / \mathrm{s}$. Sementara itu, debit pada musim kemarau diperoleh

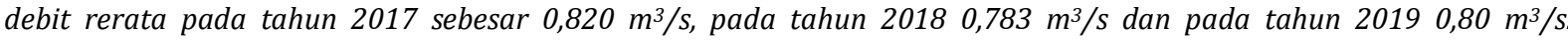
Berdasarkan hasil prediksi dengan persamaan neraca air pada musim penghujan, debit rerata diperoleh nilai sebesar $1,628 \mathrm{~m}^{3} / \mathrm{s}$ pada tahun 2017, 1,579 $\mathrm{m}^{3} / \mathrm{s}$ pada tahun 2018 dan $3,296 \mathrm{~m}^{3} / \mathrm{s}$ pada tahun 2019. Sedang kan debit rerata pada musim kemarau diperoleh nilai sebesar 1,893 $\mathrm{m}^{3} / \mathrm{s}$ pada tahun 2017, 1,176 m³ $/ \mathrm{s}$ pada tahun 2018; dan 1,893 $\mathrm{m}^{3} / \mathrm{s} \mathrm{pada}$ tahun 2019. Hasil ini menunjukkan bahwa hasil pemodelan debit dengan HEC-HMS lebih kecil dibandingkan dengan dengan hasil prediksi debit dengan persamaan neraca air. Penelitian ini menyimpulkan bahwa HEC-HMS mampu digunakan utk prediksi debit aliran masuk secara harian, namun demikian perlu dilakukan proses kalibrasi dan validasi lebih lanjut dengan merekomendasikan diadakan pemasangan stasiun monitoring debit aliran sungai di masing-masing outlet sungai.

Kata kunci: neraca air, HEC-HMS, prediksi inflow 


\section{PENDAHULUAN}

Daerah Aliran Sungai (DAS) merupakan suatu wilayah yang berfungsi sebagai penyimpanan air penyaluran air, pengumpul air dan unsur hara melalui sistem sungai lalu disalurkan menuju outlet tunggal, yakni danau atau laut (Naharuddin et al., 2018). Danau merupakan cekungan di permukaan bumi yang berisi ekosistem perairan tawar yang tergenang dengan ukuran lebih besar dibandingkan dengan kolam (Soeprobowati, 2012). Danau memiliki fungsi ekologi dan sosial. Fungsi ekologi yang merupakan habitat bagi organisme dan mengontrol keseimbangan air tanah serta fungsi sosial berupa yang merupakan tempat kegiatan masyarakat karena banyaknya ketersediaan air bersih dan fungsi ekonomi yang merupakan sumber air untuk irigasi dan sebagai sumber Pembangkit Listrik Tenaga Air (PLTA) (Couto \& Olden, 2018; Fakhrudin et al., 2002).

Salah satu danau yang digunakan untuk sumber PLTA adalah Danau Menjer. Danau Menjer atau popular dengan nama Telaga Menjer terletak di antara Desa Maron dan Desa Tlogo, Kecamatan Garung, Kabupaten Wonosobo, Provinsi Jawa Tengah (Piranti et al., 2021). Luas Daerah Tangkapan Air (DTA) Danau Menjer sekitar 2,27 $\mathrm{km}^{2}$ dengan luas permukaan air danau sekitar 0,63 $\mathrm{km}^{2}$. Air pada Danau Menjer bersumber dari hujan, suplesi dari Sungai Serayu dan sungai - sungai yang berada di sekitar DTA Menjer. Suplesi Sungai Serayu berada di sebelah timur laut Danau Menjer. Beberapa sungai utama yang berada di DTA Menjer adalah Sungai Siwedi, Sungai Silumbu, dan Sungai Menjer dengan luas subdas masing-masing yaitu $0,413 \mathrm{~km}^{2} ; 0,144 \mathrm{~km}^{2}$; dan 0,610 km². Danau Menjer memiliki fungsi utama, yaitu sebagai pemasok air Pembangkit Listrik Tenaga Air (PLTA) Garung. Fungsi lainnya, yaitu sebagai tempat pariwisata dan perikanan darat (Isfaudin \& Mandaka, 2020).

Informasi tentang neraca air dan potensi sumber daya air yang ada pada DTA Menjer diperlukan, agar pola operasi dapat berjalan secara efisien dan berkelanjutan serta tata kelola Telaga Menjer dapat berjalan dengan baik, maka dibutuhkan. Salah satu komponennya, yaitu data dan informasi debit aliran masuk dari sungai-sungai yang ada di DTA Menjer. Kendala yang ada adalah validasi data yang ada dikarenakan aliran masuk dari sungai-sungai di DTA Menjer tidak dilakukan monitoring (ungauged catchment area). Untuk memprediksi aliran yang masuk, bisa menggunakan pemodelan numerik dan hitungan neraca air. Berikut beberapa penelitian yang menggunakan piranti lunak Hydrologic
Engineering Center-Hydrologic Modeling System (HEC-HMS) untuk pemodelan perilaku air, yaitu :

1) Listyarini et al. (2018), telah melakukan penelitian mengenai mitigasi banjir pada hulu Das Citarum menggunakan model HEC-HMS. Parameter utama yang digunakan dalam perhitungan penelitian ini adalah waktu tenggang (time lag) dihitung menggunakan metode SCS Unit Hydrograph, metode baseflow menggunakan metode recession, dan metode routing menggunakan metode lag yang dihitung menggunakan persamaan Kirpich.

2) Ferdiansyah et al. (2020), telah melakukan penelitian mengenai potensi debit aliran lokal pada Waduk Saguling dengan model hujan limpasan menggunakan aplikasi HEC-HMS. Parameter penelitian ini menggunakan parameter Lag Time yang tergantung pada panjang, kemiringan dan penampang melintang sungai, dan parameter aliran dasar menggunakan linier reservoir.

3) Zulaeha et al. (2020) telah melakukan penelitian mengenai prediksi debit aliran sub-DAS Bantimurung, menggunakan model HEC-HMS. Penelitian ini untuk memperhitungkan debit aliran pada sub-DAS Bantimurung, menggunakan aplikasi HEC-HMS untuk mengetahui tingkat kevalidan pada daerah karst dalam memprediksi besarnya debit aliran.

Selain itu, penelitian perilaku air, khususnya variabel debit, juga dapat dilakukan dengan menggunakan pendekatan persamaan neraca air. Seperti halnya penelitian yang dilakukan oleh Wulandari et al. (2016) melakukan penelitian mengenai keakuratan prediksi inflow waduk dengan neraca air waduk. Penelitian ini menganalisis inflow waduk dengan beberapa komponen data yaitu data besarnya outflow waduk, penguapan, kapasitas tamping waduk, curah hujan di waduk, serta pengamatan tinggi muka air waduk yang didapat dari laporan operasi waduk.

Penelitian ini bertujuan untuk memprediksi debit aliran masuk ke telaga dari sungai-sungai yang ada di DTA Menjer. Berbeda dengan penelitian yang dilakukan oleh Listyarini (2018), Ferdiansyah (2020) dan Zulaeha (2020) yang hanya menggunakan metode HEC-HMS ataupun penelitian oleh Wulandari (2016) yang hanya menggunakan pendekatan neraca air, pada makalah ini dilakukan perhitungan debit aliran masuk dengan metode HEC-HMS dan neraca air agar diperoleh hasil yang lebih akurat. 


\section{METODE PENELITIAN}

\section{Alat dan Bahan}

Alat yang digunakan pada penelitian ini adalah laptop, perangkat lunak ArcGIS 10.2, Microsoft Excel, dan HEC-HMS. Data yang digunakan dalam penelitian ini adalah data Digital Elevation Model (DEM), peta topografi, data jaringan sungai data curah hujan, peta jenis tanah, peta penggunaan lahan, data inflow Serayu-Klakah, data pemakaian air, data tinggi muka air.

\section{HEC-HMS}

HEC-HMS adalah salah satu model hidrologi yang dikembangkan oleh USACE-HEC untuk memprediksi atau mensimulasikan proses hujan aliran (debit inflow) dari suatu sistem DAS (Scharffenberg, 2016). Program HEC-HMS ini terdiri dari tiga komponen yaitu model basin, model hidrologi, dan kontrol spesifik (Syahputra, 2015). Model ini mempunyai keluaran berupa hidrograf limpasan dalam suatu Sub-DAS pada sistem hidrologi DAS tersebut.

\section{Neraca Air}

Neraca air dapat digunakan untuk mengetahui ketersediaan air pada suatu daerah (Effendi et al., 2017) . Dalam konsep hidrologi jumlah air pada suatu luasan permukaan bumi dipengaruhi oleh besarnya jumlah air yang masuk (input) dan keluar (output) pada jangka waktu tertentu. Neraca air merupakan salah satu aspek terpenting dalam sistem hidrologi. Neraca air adalah perbandingan antara potensi ketersediaan air dengan kebutuhan air pada suatu tempat dalam periode tertentu (Mokobombang et al., 2016).

Pada pemodelan hidrologi, persamaan neraca air dapat menganalisis debit limpasan pada suatu DAS ataupun DTA (Ri et al., 2019). Persamaan neraca air untuk menghitung debit aliran masuk dapat dilakukan dengan Persamaan1.

$Q_{\text {in }}=\frac{\Delta S}{\Delta t}-(P \times A)-\left(Q_{\text {sup }} \times t\right)+(E t p \times A)+Q_{\text {out }}$

di mana :

$\begin{array}{ll}\text { Qin } & \text { : Inflow dari sungai-sungai DTA Menjer } \\ & \left(\mathrm{m}^{3} / \mathrm{s}\right) \\ \frac{\Delta S}{\Delta t} & \text { : Perubahan volume tampung }\left(\mathrm{m}^{3}\right) \\ P & \text { : Presipitasi (mm/hari); } \\ A & \text { : Luas permukaan telaga/danau }\left(\mathrm{m}^{2} / \mathrm{s}\right) ; \\ Q_{\text {sup }} & \text { : Inflow suplesi dari Serayu-Klakah }\left(\mathrm{m}^{3} / \mathrm{s}\right) ; \\ t & \text { : Waktu atau hari ke-t; } \\ \text { Etp } & \text { : Evapotranspirasi (mm/hari); } \\ \text { Qout } & \text { : Debit keluar dari Telaga Menjer }\left(\mathrm{m}^{3} / \mathrm{s}\right) .\end{array}$

\section{Curah Hujan Wilayah}

Curah hujan merupakan data input yang penting dalam pemodelan hidrologi khususnya saat mensimulasikan aliran inflow atau outflow (Tuo et al., 2016). Data curah hujan yang dianalisis berasal dari data CHIRPS (Climate Hazards Group InfraRed Precipitation with Station data) dan data observasi Stasiun hujan Menjer. Stasiun hujan yang telah diperoleh dari data CHIRPS dan data observasi Stasiun hujan Menjer memiliki titik atau lokasi yang berbeda-beda, maka hujan yang tercatat dari masing-masing lokasi juga tidak sama nilainya. Dalam analisis hidrologi, diperlukan data wilayah untuk menentukan bobot dari curah hujan rata-rata pada daerah tersebut. Metode yang digunakan untuk menentukan hujan rata-rata wilayah adalah metode polygon Thiessen dengan Persamaan 2.

$\bar{p}$

$$
=\frac{A_{1} p_{1}+A_{2} p_{2}+A_{3} p_{3+\ldots}+A_{n} p_{n}}{A_{1}+A_{2}+A_{3}+\ldots \ldots+A_{n}} .
$$

di mana :

$\bar{p} \quad$ : curah hujan rata-rata DAS (mm)

$p_{1}, p_{2}, \ldots p_{n} \quad:$ curah hujan pada stasiun $1,2, \ldots \mathrm{n}$ (mm)

$A_{1}, A_{2}, \ldots A_{n} \quad$ : luas area yang mewakili stasiun 1 , $2, \ldots . \mathrm{n}\left(\mathrm{km}^{2}\right)$

\section{Evapotranspirasi}

Evapotranspirasi merupakan hilangnya air dari suatu wilayah melalui gabungan antara proses evaporasi dan transpirasi (Supangat, 2016). Evapotranspirasi merupakan komponen penting dalam keseimbangan siklus hidrologi di suatu wilayah (Ma et al., 2018). Besar atau kecilnya nilai evapotranspirasi dari suatu bentang lahan penting diketahui, terutama kaitanya dalam sumber daya lahan, perencanaan pengelolaan sumber daya air, dan pertanian secara umum.

Dalam penelitian ini menggunakan rumus empiris Thornthwaite untuk menghitung evapotranspirasi potensial. Untuk menganalisis evapotranpirasi dapat dilihat pada Persamaan 3.

$E T_{\text {bulan }}=1,62\left(\frac{10 . T m}{5}\right)^{a}$

dengan:

$a=675 \times 10^{-9} I^{3}-771 \times 10^{-7} I^{2}+179 \times 10^{-4} I+$ $492 \times 10^{-3}$

$I=\sum_{m=1}^{12}\left(\frac{T m}{5}\right) 1,514$

di mana :

$E T_{\text {bulan }}$ : Evapotranspirasi potensial bulanan $(\mathrm{cm})$

$T_{m} \quad$ : Temperature bulanan rerata $\left({ }^{\circ} \mathrm{C}\right)$

I : Indeks panas tahunan 


\section{Volume Aliran (Volume Runoff)}

Komponen volume run-off pada penelitian ini dihitung dengan menggunakan metode SCS Curve Number yang berfungsi untuk memperkirakan hujan lebihan atau hujan efektif sebagai bagian dari hujan yang menjadi aliran langsung di sungai. Beberapa parameter SCS Curve Number adalah initial abstraction (Ia), bilangan kurva aliran (curve number) dan lapisan kedap air (impervious). Perhitungan volume limpasan dengan menggunakan Persamaan 6 (Scharffenberg, 2016):

$$
P e \quad=\frac{(P-I a) 2}{P-I a+S}
$$

di mana :

$$
\begin{array}{llr}
P e & : \text { hujan kumulatif pada waktu } \mathrm{t}(\mathrm{mm}) \\
P & \begin{array}{l}
\text { : kedalaman hujan kumulatif pada waktu t } \\
(\mathrm{mm})
\end{array} \\
\text { Ia } & \begin{array}{l}
\text { : kehilangan mula-mula } \\
\text { Abstraction })(\mathrm{mm})
\end{array} \\
& \begin{array}{l}
\text { (Initial } \\
\text { S kemampuan penyimpanan }
\end{array} & \\
& (\mathrm{mm})
\end{array}
$$

Initial abstraction merupakan proses kehilangan air sebelum terjadinya hujan. Proses ini dipengaruhi oleh air yang ditahan oleh tekanan permukaan, air yang diintersep oleh tumbuh-tumbuhan, penguapan, dan inflitrasi. Besarnya kehilangan awal ( $\mathrm{I}_{\mathrm{a}}$ ) dapat dihitung dengan Persamaan 7.

Ia $=0.2 S$.

Hubungan antara nilai kemampuan penyimpanan maksimum dengan nilai dari karakteristik DAS yang diwakili oleh nilai CN (Curve Number) adalah sebagai berikut:

$\mathrm{S}=\frac{25400-254 C N}{C N}$

di mana :

$\mathrm{S} \quad$ : Parameter retensi
$\mathrm{CN} \quad$ : Curve number

\section{Metode aliran langsung (direct runoff)}

Aliran langsung merupakan hujan yang langsung tersalur suatu aliran menuju sungai di atas permukaan tanah. Pada penelitian ini model yang akan digunakan adalah model unit hidrograf SCS. Parameter utama yang dibutuhkan adalah lag time/waktu tenggang antara titik berat hujan efektif dengan titik berat hidrograf. Lag time dapat ditentukan dengan Persamaan 9.

$T_{\text {lag }}=0.6 \times t_{\text {... }}$

dengan

$T c=0.57 A^{0.41}$ di mana :

Tc : Waktu konsentrasi (jam)

$A \quad$ : Luas wilayah $\left(\mathrm{km}^{2}\right)$

\section{Aliran dasar (Baseflow)}

Baseflow merupakan debit air yang terdapat di sungai pada saat musim kemarau, atau pada saat tidak terjadi hujan sama sekali (Indarto, 2010). Aliran baseflow berasal dari air hujan yang terinfiltrasi menjadi cadangan air tanah, lalu pada lokasi tertentu mengalir dan menyatu dengan debit sungai yang lain. Besarnya debit aliran dasar (Qb) diperoleh dengan melakukan pengukuran di lapangan pada kondisi musim kemarau.

\section{Pengumpulan Data dan Analisis}

Data yang digunakan dalam penelitian ini berupa:

1 Peta Topografi skala 1:25000 bersumber dari Badan Informasi Geospasial.

2 Peta penggunaan Lahan SubDAS Menjer.

3 Data curah hujan tahun 2017-2019 yang diperoleh dari stasiun Menjer dan data global CHIRPS.

4 Data Meteorologi tahun 2017-2019 yang diperoleh dari BMKG.

5 Data Pemakaian Air PLTA Garung tahun 20172019 dari PLTA Sub Unit Garung.

6 Data debit air harian terukur tahun 2017-2019 yang diperoleh dari PLTA Sub Unit Garung.

7 Data tinggi muka air Danau Menjer dari PLTA Sub Unit Garung dari tahun 2017-2019.

\section{Delineasi DAS dengan Hec-GeoHMS}

Delineasi batas DAS dilakukan dengan menggunakan data DEM dan jaringan sungai. Proses ini dilakukan dengan software ArcGIS dengan extention HEC-GeoHMS. Proses delineasi diawali dengan melakukan beberapa analisis terrain processing antara lain: DEM reconditioning, fill sink, flow direction, flow accumulation, stream definition, stream segmentation, catchment grid delineation, drainage line processing, adjoint catchment dan processing. Selanjutnya input posisi outlet untuk menghasilkan satu wilayah DAS beserta komponen hidrologinya (sub-DAS, reach, junction dan sink).

\section{Input model HEC-HMS}

\section{Menyusun model basin}

Penelitian ini menggunakan beberapa elemen input data yaitu curve number, initial abstraction, dan Percent impervious. Input data pada masingmasing parameter adalah: 
1) Curve Number

Proses menghitung nilai $\mathrm{CN}$ gabungan berdasarkan klasifikasi jenis lahan di tiap Sub DAS untuk menghasilkan nilai CN tiap Sub DAS.

2) Initial Abstraction

Initial abstraction merupakan nilai kehilangan mula-mula dimana pada proses ini sangat berkaitan dengan nilai $\mathrm{S}$ (kemampuan penyimpanan maksimum).

3) Percent impervious

Parameter yang berpengaruh terhadap volume limpasan suatu DAS adalah luas daerah impervious (kekedapan terhadap air). Faktor Impervious Area berdasarkan Tipe Penggunaan Lahan untuk model hidrologi HEC-HMS terlihat pada Tabel 1.

Tabel 1 Persen Impervious

\begin{tabular}{l|c}
\multicolumn{1}{c|}{ Penggunaan Lahan } & Persen Impervious \\
\hline Pohon & 0 \\
\hline Rumput & 5 \\
\hline Pemukiman sedikit penduduk & 20 \\
\hline Pemukiman banyak penduduk & 30 \\
\hline Komersial & 85 \\
\hline Air & 100 \\
\hline Sumber : Scharffenberg, 2016 &
\end{tabular}

\section{Penyusunan model meteorologi}

Input data meteorologi yang digunakan yaitu data curah hujan harian dari tahun 2017-2019.

\section{Kontrol spesifikasi}

Pada control specification digunakan untuk pengisian tanggal dimulai dan diakhiri serta jangka waktu yang dibutuhkan. Waktu simulasi yang digunakan pada penelitian ini dari 1 Januari 2017 30 September 2019.

\section{Time series data}

Proses ini merupakan tampilan dalam bentuk tabel dan hidrograf yang dihasilkan dari curah hujan sebagai input.

\section{Simulasi model HEC-HMS}

Setelah menginput data masukan pada model maka model akan dijalankan sehingga menghasilkan keluaran berupa hidrograf dan data debit harian.

\section{Prediksi Inflow dengan Neraca Air}

\section{Volume air dan Luas Permukaan Danau}

Dalam analisis volume air dan luas permukaan menggunakan data pemeruman/kedalaman danau yang diperoleh dari data observasi di lapangan. Data pemeruman yang diperoleh lalu di input ke ArcGIS dengan format point kemudian formatnya diubah menjadi TIN untuk menggambarkan tampungan menjadi 3D. Kemudian menggunakan perintah tool surface volume untuk mengetahui volume air dan luas permukaan danau.

\section{Curah hujan wilayah}

Data curah hujan yang dianalisis bersumber dari data CHIRPS dan data observasi stasiun hujan Menjer tahun 2017-2019.

\section{Evapotranspirasi}

Data evapotranspirasi pada penelitan ini berdasarkan hasil analisis menggunakan metode Thornthwaite Mather dengan data meteorologi bersumber dari BMKG Jawa Tengah tahun 2017 2019.

Proses analisis evapotranspirasi menggunakan metode Thornthwaite Mather (Triatmodjo, 2013), diawali dengan menghitung indeks panas seluruh bulan dengan Persamaan 5, kemudian hitung nilai a berdasarkan nilai indeks panas yang diperoleh dengan Persamaan 4 dari hasil perhitungan tersebut maka kemudian dapat dihitung evapotranspirasi dengan Persamaan 3.

\section{Debit Inflow Suplesi}

Data debit suplesi bersumber dari data debit Serayu-Klakah yang dicatat bendungan yang terletak di sebelah timur laut Danau Menjer yang kemudian dialirkan melewati terowongan/tunnel menuju Danau Menjer.

\section{Pemakaian Air}

Data ini akan digunakan sebagai debit keluar/outflow dari Danau Menjer yang akan digunakan sebagai pemasok listrik pada PLTA Garung.

\section{Perhitungan prediksi inflow dengan neraca air}

Setelah diperoleh komponen yang dibutuhkan maka inflow dari sungai-sungai di DTA Menjer dapat diketahui sehingga analisis debit aliran dengan pendekatan neraca air dapat dilakukan dengan Persamaan 1.

\section{HASIL DAN PEMBAHASAN \\ Karakteristik fisik DAS Menjer}

Daerah Tangkapan Air Menjer memiliki 3 Daerah Aliran sungai yang menjadi inflow menuju Danau Menjer. Data karakteristik DAS tersebut didapatkan dengan menggunakan software ArcMap 10.2 dapat ditampilkan pada Tabel 2 . 
Tabel 2 Data karakteristik DAS Menjer

\begin{tabular}{|c|c|c|c|c|}
\hline Karakteristik & Satuan & $\begin{array}{l}\text { Sungai } \\
\text { Menjer }\end{array}$ & $\begin{array}{c}\text { Sungai } \\
\text { Silumb } \\
\mathrm{u}\end{array}$ & $\begin{array}{l}\text { Sungai } \\
\text { Siwedi }\end{array}$ \\
\hline Luas sub DAS & $\mathrm{km}^{2}$ & 0,610 & 0,144 & 0,413 \\
\hline $\begin{array}{l}\text { Jenis lahan: } \\
\text { Tegalan/Ladan } \\
\text { g }\end{array}$ & $\%$ & 6,2 & 8,3 & 20,1 \\
\hline Semak Belukar & $\%$ & 14,1 & - & 0,2 \\
\hline $\begin{array}{l}\text { Sawah Tadah } \\
\text { Hujan }\end{array}$ & $\%$ & 63,6 & 82,6 & 65,6 \\
\hline $\begin{array}{l}\text { Perkebunan/ } \\
\text { Kebun }\end{array}$ & $\%$ & 16,1 & 9,1 & 14,1 \\
\hline $\begin{array}{l}\text { Jenis Tanah: } \\
\begin{array}{l}\text { Andesol } \\
\text { Litik }\end{array}\end{array}$ & $\%$ & 3,1 & - & - \\
\hline $\begin{array}{l}\text { Andesol } \\
\text { Umbrik }\end{array}$ & $\%$ & 93,4 & 90,1 & 80,1 \\
\hline$>$ Litosol & $\%$ & 3,5 & 9,9 & 19,9 \\
\hline $\begin{array}{l}\text { Panjang } \\
\text { sungai } \\
\text { utama }\end{array}$ & $\mathrm{km}$ & 2,06 & 1,02 & 1,33 \\
\hline Elevasi hulu & $\mathrm{m}$ & 2175,7 & $\begin{array}{c}1742,9 \\
1\end{array}$ & 1944,1 \\
\hline Elevasi hilir & $\mathrm{m}$ & 1296,3 & $\begin{array}{c}1278,5 \\
4\end{array}$ & 1232,9 \\
\hline $\begin{array}{l}\text { Kemiringan / } \\
\text { slope DAS }\end{array}$ & - & 0,43 & 0,35 & 0,54 \\
\hline
\end{tabular}

\section{Pengaruh Curah Hujan}

Curah hujan merupakan masukan penting dalam penelitian ini. Data curah hujan yang digunakan pada penelitian ini berupa data CHIRPS yang dikoreksi dengan data hujan pengamatan dari stasiun hujan Indonesia Power Sub Unit PLTA Garung.

Berdasarkan Peraturan Direktur Jenderal Bina Pengelolaan Daerah Aliran Sungai Dan Perhutanan Sosial (2013) Nomor P.4/V-Set/2013 tentang petunjuk teknis penyusunan data spasial lahan kritis, maka curah hujan di DTA Menjer dikategorikan sangat tinggi dengan nilai $\geq 3000$ $\mathrm{mm} /$ tahun. DTA Menjer dengan rentang waktu 1 Januari 2017 - 30 September 2019.

\section{Kemiringan Lereng}

Kelas kemiringan lereng DTA Menjer dibagi ke dalam 5 kategori yaitu 0-8\%, 9-15\%, 16-25\%, 26$40 \%$ dan $>40 \%$. Klasifikasi tersebut dilakukan berdasarkan Peraturan Direktur Jenderal Bina Pengelolaan Daerah Aliran Sungai Dan Perhutanan Sosial (2013) Nomor P.4/V-Set/2013. Kelas kemiringan lereng yang didominasi oleh kelas sangat curam (>40\%) dengan luas 53,98 hektar.

\section{Peta Jenis Tanah}

Terdapat 3 jenis tanah yang tersebar di DTA Menjer. Jenis tanah DTA Menjer yang mendominasi adalah tanah asosiasi landform tektonik, andosol umbrik, dengan tekstur sedang, drainase yang baik, bentuk wilayah bergunung sangat curam dengan bahan induk abu dan pasir volkan andesitis sebesar 103,4 ha, disusul oleh tanah asosiasi landform tektonik, litosol, dengan tekstur agak kasar, drainase sedang, bentuk wilayah bergunung curam dengan bahan induk abu dan pasir volkan andesitas sebesar 11,43 ha.

\section{Tata Guna Lahan}

Penggunaan lahan pada penelitian ini dapat diklasifikasikan menjadai beberapa jenis lahan antara lain sawah tadah hujan, tegalan atau ladang, perkebunan/kebun, dan semak belukar. Untuk informasi peta sebaran Tata Guna Lahan DTA Menjer disajikan pada Tabel 2.

\section{Pemodelan debit simulasi HEC-HMS}

Elemen-elemen yang digunakan untuk simulasi limpasan pada penelitian ini adalah subbasin dan junction. Subbasin pada DTA menjer terlihat pada Gambar 1, Gambar 2 , dan Gambar 3.

\section{Parameter permodelan}

Dalam memodelkan debit inflow DTA Menjer di HEC-HMS digunakan model perhitungan SCS CN (Soil Conservation Service Curve number). Ada 3 parameter penting yang menjadi dasar permodelan metode SCS yaitu loss rate method, SCS Transform dan baseflow.

\section{Loss method}

Nilai Curve number dan impervious di setiap subbasin mengasumsikan tingkat permeabilitas atau persentase resapan air tanah berdasarkan nilai tata guna lahan. Adapun nilai curve number, initial abstraction, dan impervious tanah dapat dilihat pada Tabel 3, Tabel 4, dan Tabel 5. 


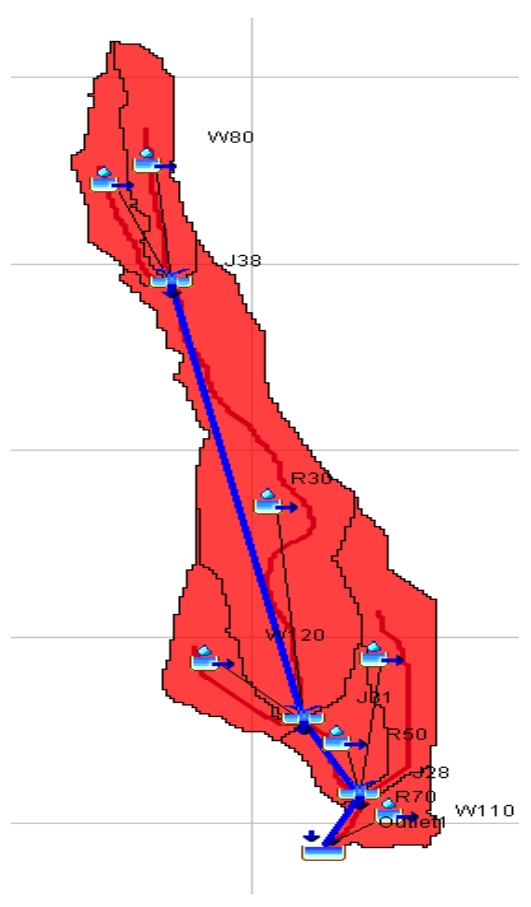

Gambar 1 Skema pemodelan Sungai Menjer

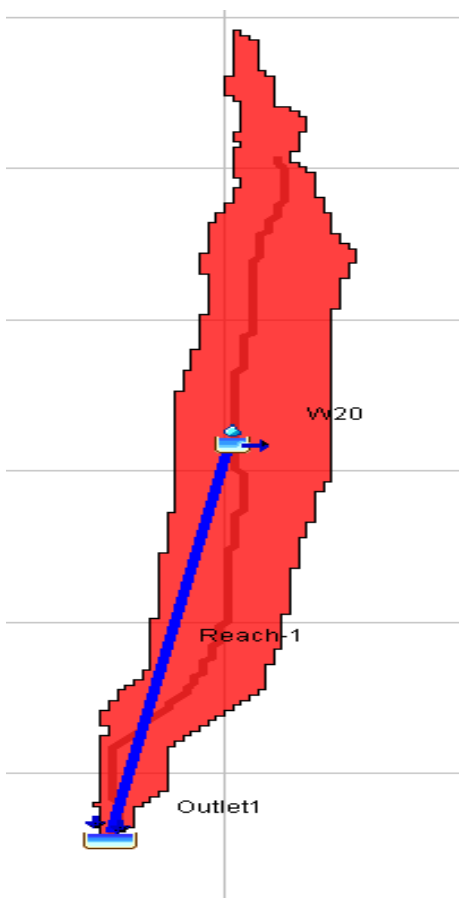

Gambar 2 Skema pemodelan Sungai Silumbu

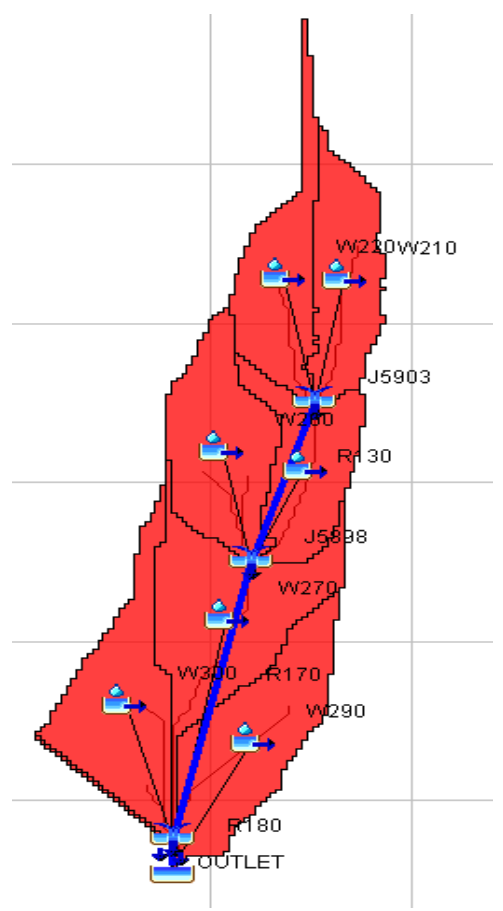

Gambar 3 Skema pemodelan Sungai Siwedi
Tabel 3 Nilai SCS CN Sungai Menjer

\begin{tabular}{l|c|c|c}
\hline \multicolumn{4}{c}{ Sungai Menjer } \\
\hline Subbasin & la (mm) & CN & IMP (\%) \\
\hline W140 & 15,149 & 77,030 & 5 \\
\hline W130 & 15,310 & 76,842 & 5 \\
\hline W120 & 16,753 & 75,200 & 5 \\
\hline W110 & 15,573 & 76,537 & 5 \\
\hline W100 & 16,270 & 75,742 & 5 \\
\hline W90 & 22,878 & 68,949 & 5 \\
\hline W80 & 20,343 & 71,406 & 5 \\
\hline
\end{tabular}

\section{Transform Method}

Dalam penelitian ini, nilai SCS Transform dapat diasumsikan sama rata dengan graph time standard pada setiap subbasin. Nilai parameter lag time dapat dilihat pada Tabel 6 , Tabel 7 , dan Tabel 8.

Tabel 4 Nilai SCS CN Sungai Silumbu

\begin{tabular}{lccc}
\hline \multicolumn{4}{c}{ Sungai Silumbu } \\
\hline Subbasin & la $(\mathrm{mm})$ & $\mathrm{CN}$ & IMP (\%) \\
\hline W20 & 16,978 & 74,95 & 5 \\
\hline
\end{tabular}

Tabel 5 Nilai SCS CN Sungai Siwedi

\begin{tabular}{l|c|c|c}
\hline \multicolumn{4}{|c}{ Sungai Siwedi } \\
\hline Subbasin & la $(\mathrm{mm})$ & $\mathrm{CN}$ & IMP (\%) \\
\hline W300 & 9,8750 & 83,725 & 5 \\
\hline W270 & 12,546 & 80,194 & 5 \\
\hline W260 & 12,687 & 80,016 & 5 \\
\hline W230 & 12,680 & 80,025 & 5 \\
\hline W220 & 10,778 & 82,497 & 5 \\
\hline W210 & 10,505 & 82,865 & 5 \\
\hline W290 & 14,270 & 78,070 & 5 \\
\hline
\end{tabular}

Tabel 6 Lag Time Sungai Menjer

\begin{tabular}{l|c|c}
\hline \multicolumn{1}{c|}{ Subbasin } & Graph Time & Lag Time (Min) \\
\hline W140 & Standart & 9,91 \\
\hline W130 & Standart & 5,70 \\
\hline W120 & Standart & 8,81 \\
\hline W110 & Standart & 12,78 \\
\hline W100 & Standart & 22,34 \\
\hline W90 & Standart & 24,99 \\
\hline W80 & Standart & 22,3 \\
\hline
\end{tabular}


Tabel 7 Lag Time Sungai Silumbu

\begin{tabular}{l|c|c}
\hline \multicolumn{1}{c|}{ Subbasin } & Graph Time & Lag Time (Min) \\
\hline W20 & Standart & 16,98 \\
\hline
\end{tabular}

\section{Baseflow Method}

Baseflow merupakan aliran dasar sungai. Nilai baseflow terjadi akibat limpasan yang berasal dari kejadian presipitasi terdahulu yang tersimpan secara temporer pada DTA Menjer. Biasanya nilai baseflow di dapat dari pengamatan di lapangan/observasi tetapi dikarenakan keterbatasan data yang dimiliki maka dilakukan pendekatan secara empiris.

Hasil dari pemodelan HEC-HMS di DTA Menjer, debit pada ketiga sungai dengan debit tertinggi cenderung terjadi pada musim penghujan dengan nilai rerata pada tahun 2017 sebesar 0,954 m³ $/ \mathrm{s}$, pada tahun 2018 sebesar $0,944 \mathrm{~m}^{3} / \mathrm{s}$, dan pada

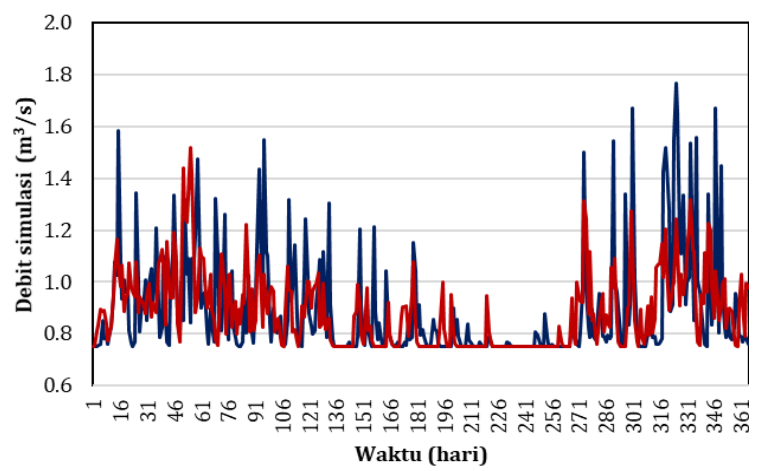

— Inflow Menjer (Sta Menjer) —_Inflow Menjer (CHIRPS)

Gambar 4 Perbandingan Inflow Menjer tahun 2017 tahun 2019 sebesar 1,017 $\mathrm{m}^{3} / \mathrm{s}$. Sedangkan debit terkecil terjadi pada pertengahan musim kemarau dengan nilai rerata pada tahun 2017 sebesar 0,820 $\mathrm{m}^{3} / \mathrm{s}$, pada tahun 2018 sebesar $0,783 \mathrm{~m}^{3} / \mathrm{s}$, dan pada tahun 2019 sebesar $0,80 \mathrm{~m}^{3} / \mathrm{s}$.

Tabel 8 Lag Time Sungai Siwedi

\begin{tabular}{l|c|c}
\hline \multicolumn{1}{c|}{ Subbasin } & Graph Time & Lag Time (Min) \\
\hline W300 & Standart & 13,01 \\
\hline W270 & Standart & 25,47 \\
\hline W260 & Standart & 13,02 \\
\hline W230 & Standart & 16,73 \\
\hline W220 & Standart & 6,98 \\
\hline W210 & Standart & 7,47 \\
\hline W290 & Standart & 14,84 \\
\hline
\end{tabular}

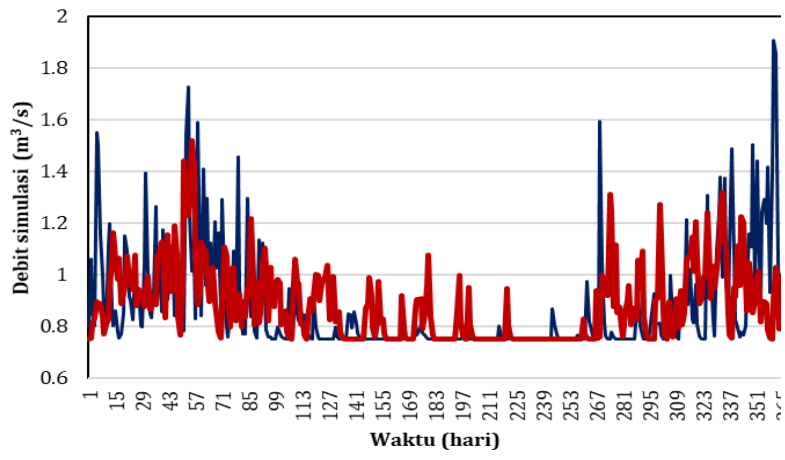

—Inflow Menjer (Sta Menjer) - Inflow Menjer (CHIRPS)

Gambar 5 Perbandingan Inflow Menjer tahun 2018

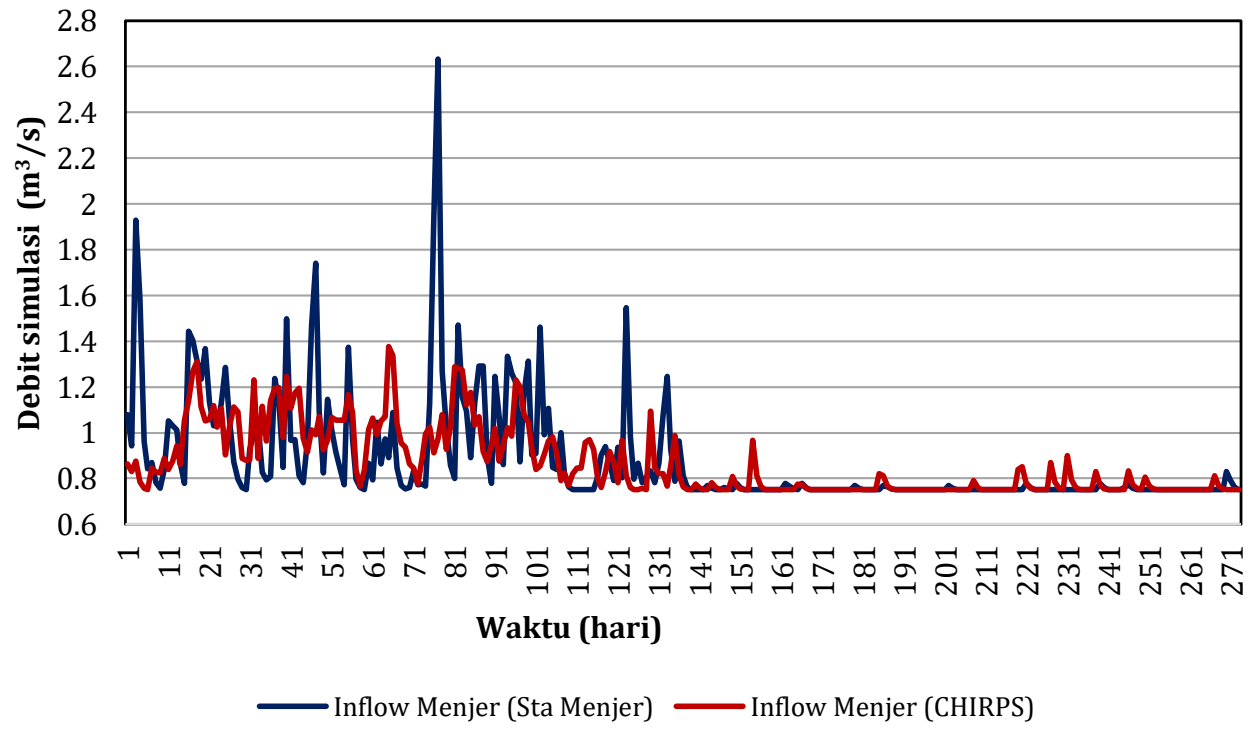

Gambar 6 Perbandingan Inflow Menjer tahun 2019 


\section{Prediksi Inflow dengan Neraca Air}

\section{Hubungan TMA - Volume Air - Luas Permukaan Danau}

Data bathimetri yang diperolah di-input ke Arcgis dengan format point kemudian format tersebut diubah menjadi TIN untuk menggambarkan tampungan menjadi 3D. Setelah diolah, maka diperoleh kedalaman Danau Menjer \pm $37 \mathrm{~m}$. Gambar 7 menunjukkan bahwa grafik hubungan TMA - Luas permukaan Danau - Volume air Danau tergolong baik. Hal ini karena data yang digunakan adalah data yang dapat mewakili titik terendah hingga tertinggi. Gambar 8 menunjukkan luas permukaan air danau tiap harinya dan Gambar 9 menunjukkan volume air danau tiap harinya.
Dari hasil analisis tersebut diketahui bahwa pada awal musim kemarau terjadi kenaikan volume air, sebaliknya terjadi penurunan pada awal musim hujan. Hal ini dipengaruhi karena adanya pola operasi PLTA yang meningkatkan kapasitas produksi air. Pada akhir musim kemarau termasuk awal musim penghujan dilakukan proses melepas air agar kapasitas tampung waduk cukup pada waktu musim penghujan sehingga tidak terjadi banjir. Di sisi lain, massa air masih tersedia ketika masuk musim kemarau.

\section{Evapotranspirasi}

Dari hasil analisis yang telah dilakukan menggunakan metode Thornthwaite Mather maka di dapatkan evapotranspirasi harian Danau Menjer pada tahun 2017-2019. Grafik evapotranspirasi terlihat pada Gambar 10.

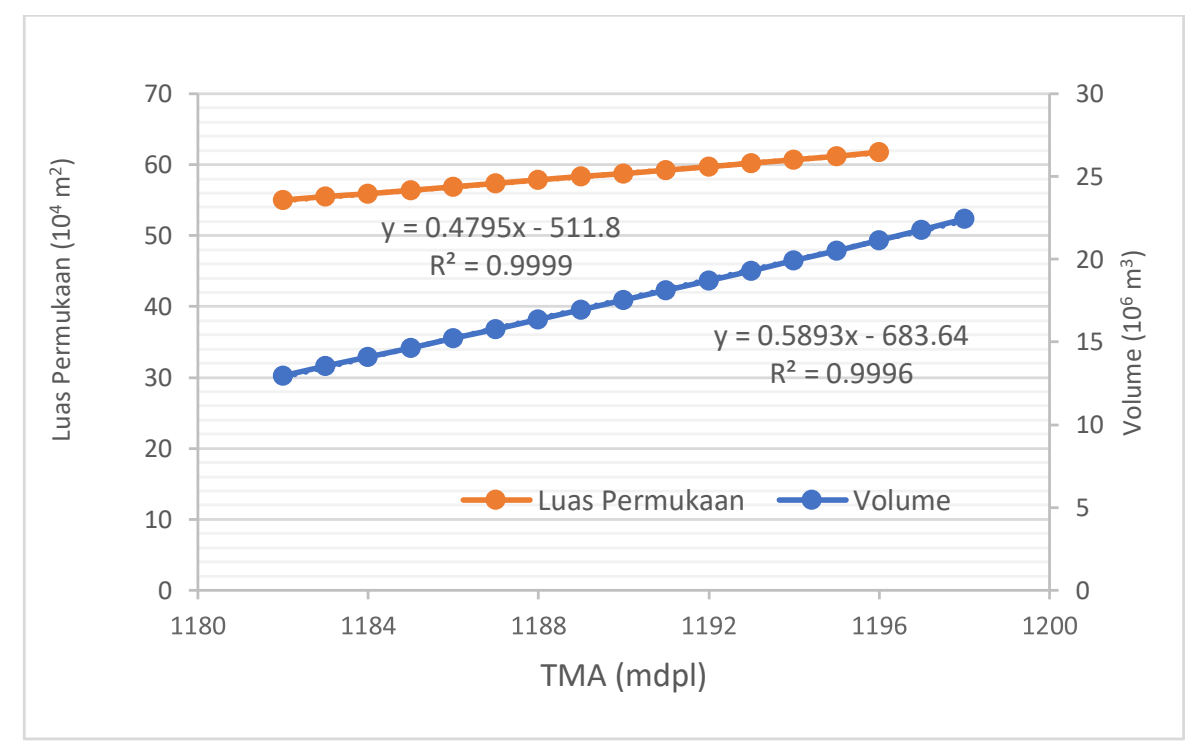

Gambar 7 Gafik hubungan TMA-Luas permukaan-Volume air Danau

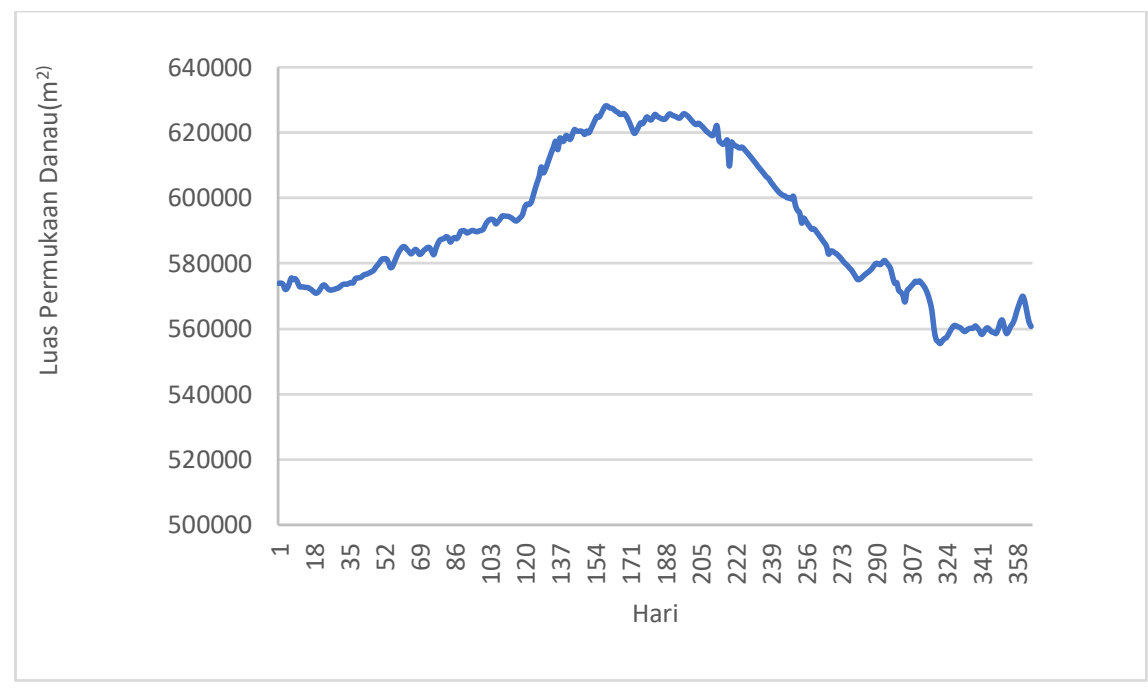

Gambar 8 Grafik luas permukaan air danau 


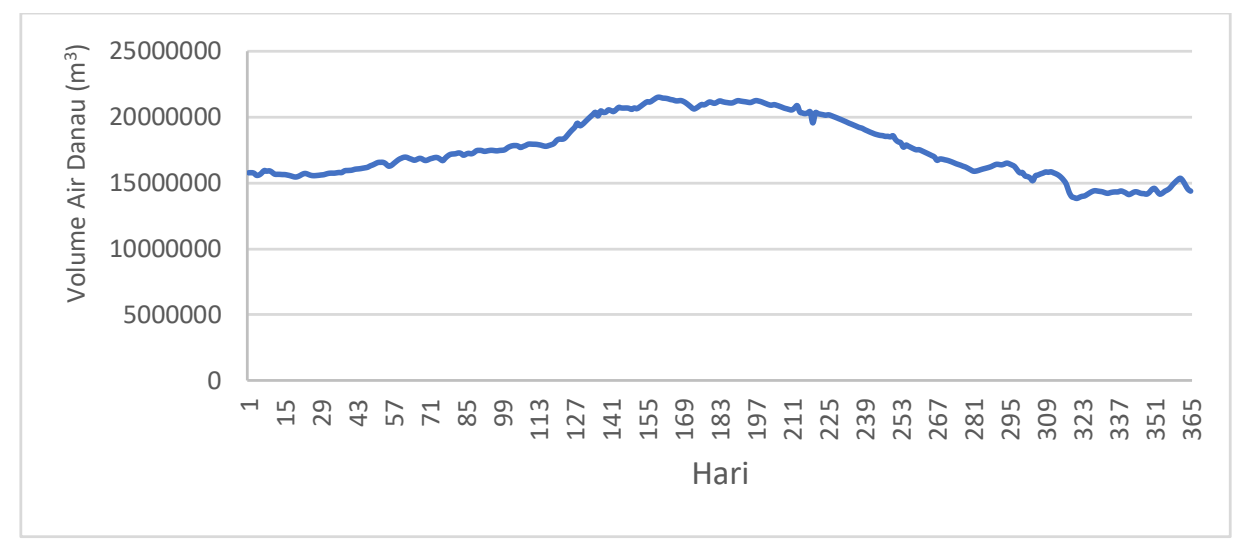

Gambar 9 Grafik volume air danau

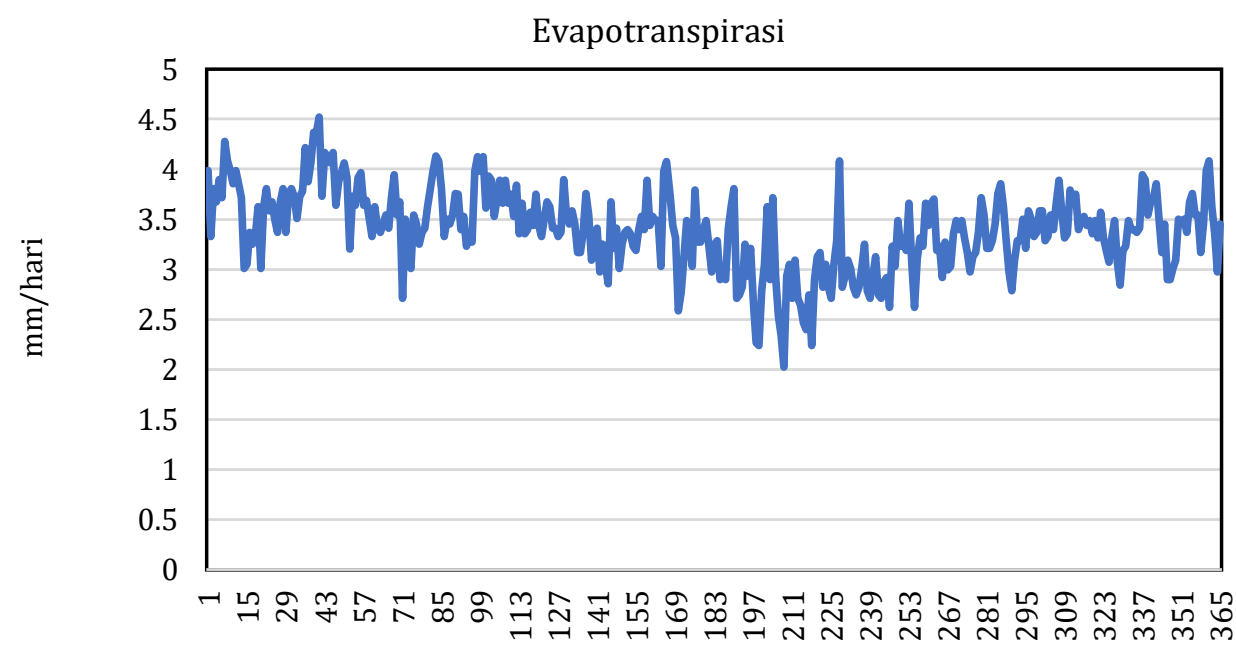

Hari

Gambar 10 Evapotranspirasi DTA Menjer

\section{Prediksi Debit Inflow dari Sungai-sungai di Danau Menjer}

Debit inflow dianalisis menggunakan persamaan neraca air dengan beberapa komponen yaitu tinggi muka air, curah hujan, luas permukaan danau, debit inflow Serayu-Klakah, evapotranspirasi, dan pemakaian air. Dari analisis dengan persamaan 1, diperoleh perkiraan debit dari sungai utama di DTA Menjer. Estimasi total debit inflow dari Sungai Menjer, Sungai Silumbu dan Sungai Siwedi, dengan persamaan dapat dilihat pada Gambar 11.

Berdasarkan hasil perhitungan inflow harian danau dari sungai-sungai di sekitarnya dengan menggunakan neraca air diperoleh inflow yang bervariasi. Hal ini dapat disebabkan karena beberapa hal yaitu curah hujan, inflow dari SerayuKlakah, dan pemakaian air yang besar sementara tinggi muka air kecil, begitu juga sebaliknya. Debit rerata diperoleh nilai sebesar $1,628 \mathrm{~m}^{3} / \mathrm{s}$ pada tahun $2017,1,579 \mathrm{~m}^{3} / \mathrm{s}$ pada tahun 2018 dan 3,296 $\mathrm{m}^{3}$ /s pada tahun 2019 . Sedangkan debit rerata pada musim kemarau diperoleh nilai sebesar 1,893 m³ $/ \mathrm{s}$ pada tahun 2017, 1,176 $\mathrm{m}^{3} / \mathrm{s}$ pada tahun 2018; dan $1,893 \mathrm{~m}^{3} / \mathrm{s}$ pada tahun 2019 .

Estimasi debit aliran ketiga sungai dengan pendekatan neraca air danau menghasilkan nilai yang lebih variatif dibandingan dengan hasil pemodelan HEC-HMS, dikarenakan banyaknya variabel neraca air lainnya seperti evapotranspirasi potensial (ETP), outflow telaga, groundwater (tidak dihitung). Berdasarkan hasil ini maka komparasi perhitungan inflow dengan model hidrologi tidak dapat dibandingkan secara langsung dengan hasil estimasi inflow dengan metode neraca air. Selain itu dengan adanya pengaruh operasional PLTA Menjer terhadap fluktuasi TMA Danau menyebabkan kemungkinan hasil perhitungan dari ketiga sungai tersebut menjadi overestimate pada kondisi TMA danau tinggi, dan sebaliknya kemungkinan terjadi underestimate (sampai negatif) dalam perhitungan selama TMA rendah. 


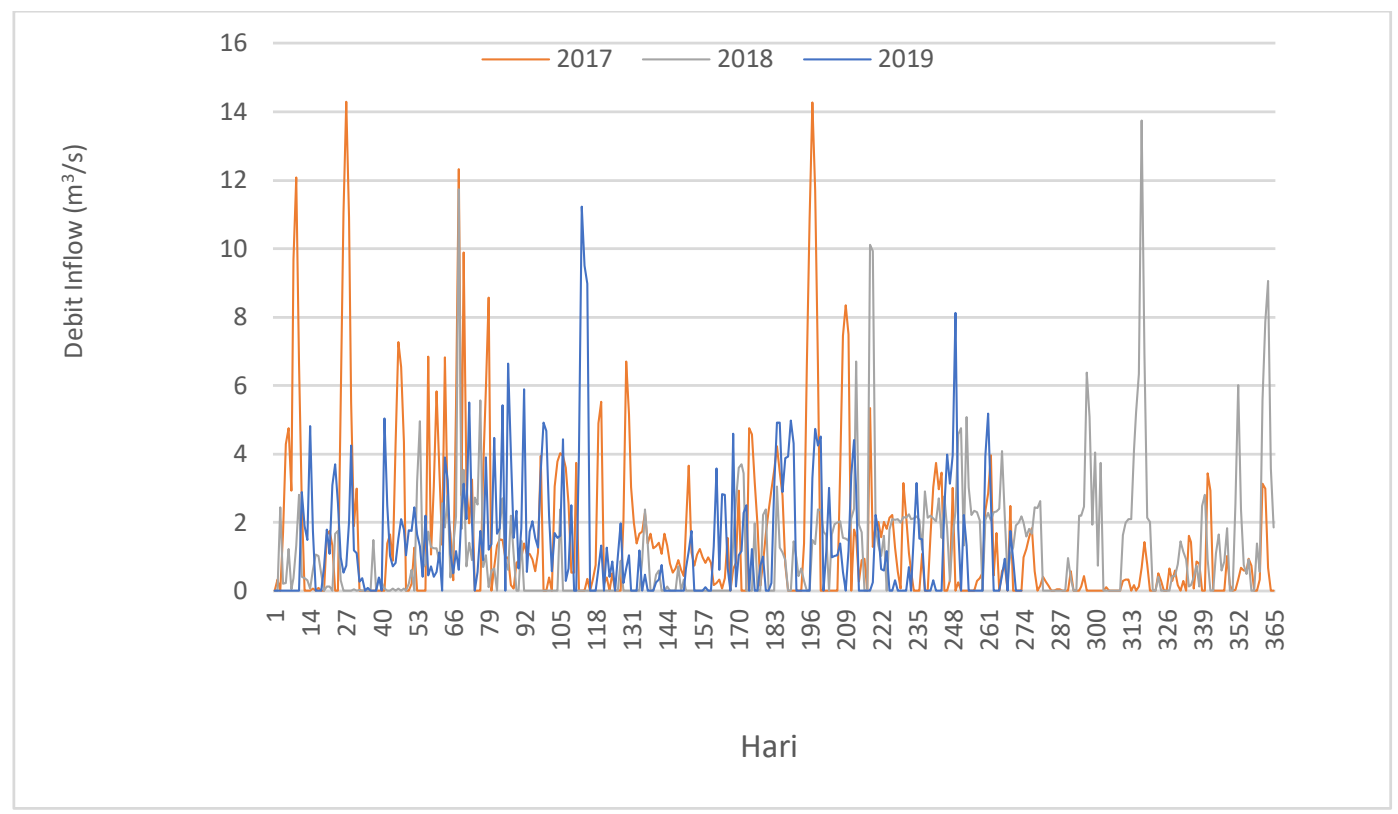

Gambar 11 Inflow debit total dari sungai-sungai di DTA Menjer

\section{Rekomendasi}

Berdasarkan penelitian ini bahwa pemodelan HEC-HMS dapat digunakan untuk memprediksi debit aliran masuk secara harian. Pemasangan alat monitoring debit aliran sungai di salah satu sungai yang ada di DTA Menjer adalah keperluan dan rekomendasi teknis yang diperlukan untuk perbaikan hasil estimasi inflow dan pemodelan respon hidrologi dengan model HEC-HMS. Hasil observasi debit sungai nantinya dapat dipergunakan utk proses kalibrasi dan validasi luaran model tersebut. Seperti disebutkan di atas, sampai saat ini tidak ada fasilitas monitoring debit aliran sungai di DTA Menjer, kecuali hanya debit inflow dari saluran buatan yang menghubungkan Sungai Serayu hulu dan Telaga Menjer.

\section{KESIMPULAN}

Berdasarkan hasil pemodelan dan analisis yang telah didapatkan, dapat disimpulkan sebagai berikut. Berdasarkan hasil analisis spasial di ArcGIS, terdapat beberapa parameter karakteristik fisik subDAS, yakni luas, kemiringan lereng, nilai CN dan persentase impervious. Untuk luas wilayah subDAS Menjer 0,61 km², Sungai Silumbu 0,144 km², dan Sungai Siwedi $0,413 \mathrm{~km}^{2}$. Sungai terpanjang yaitu sungai Menjer dengan panjang 2,06 km. Pada DTA Menjer terdapat beberapa jenis tanah yaitu tanah asosiasi landform tektonik, andosol umbrik, dengan tekstur sedang, drainase yang baik, bentuk wilayah bergunung sangat curam dengan bahan induk abu dan pasir volkan andesitis dan tanah asosiasi landform tektonik, litosol, dengan tekstur agak kasar, drainase sedang, bentuk wilayah bergunung curam dengan bahan induk abu dan pasir volkan andesitas.

Hasil dari pemodelan HEC-HMS di DTA Menjer, debit pada ketiga sungai dengan debit tertinggi cenderung terjadi pada musim penghujan dengan nilai rerata pada tahun 2017 sebesar $0,954 \mathrm{~m}^{3} / \mathrm{s}$, pada tahun 2018 sebesar $0,944 \mathrm{~m}^{3} / \mathrm{s}$, dan pada tahun 2019 sebesar 1,017 $\mathrm{m}^{3} / \mathrm{s}$. Sedangkan debit terkecil terjadi pada pertengahan musim kemarau dengan nilai rerata pada tahun 2017 sebesar 0,820 $\mathrm{m}^{3} / \mathrm{s}$, pada tahun 2018 sebesar $0,783 \mathrm{~m}^{3} / \mathrm{s}$, dan pada tahun 2019 sebesar $0,80 \mathrm{~m}^{3} / \mathrm{s}$. Dengan demikian pemodelan HEC-HMS dapat digunakan untuk memprediksi debit aliran masuk secara harian.

Berdasarkan persamaan neraca air, maka diperoleh debit inflow dari tahun 2017-2019 yang lebih variatif. Estimasi Debit aliran ketiga sungai dengan pendekatan neraca air danau menghasilkan nilai yang lebih variatif akibat banyaknya variabel neraca air lainnya seperti ETP, outflow telaga, dan groundwater.

\section{UCAPAN TERIMA KASIH}

Penulis mengucapkan terima kasih kepada Kepala Lembaga Ilmu Pengetahuan Indonesia (LIPI) yang telah mengijinkan penulis melakukan penelitian di LIPI. Penulis juga mengucapkan terima kasih kepada Universitas Muhammadiyah Yogyakarta atas dukungan finansial dalam penelitian ini. 


\section{DAFTAR PUSTAKA}

Couto, T. B. A., \& Olden, J. D. (2018). Global proliferation of small hydropower plants - science and policy. In Frontiers in Ecology and the Environment (Vol. 16, Issue 2, pp. 91-100). Wiley Blackwell. https://doi.org/10.1002/fee.1746

Direktur Jenderal Bina Pengelolaan Daerah Aliran Sungai Dan Perhutanan Sosial. (2013). Petunjuk Teknis Penyusunan Data Spasial Lahan Kritis. In Peraturan Direktur Jenderal Bina Pengelolaan Daerah Aliran Sungai Dan Perhutanan Sosial Nomor P.4/V-SET/2013.

Effendi, R., Rizal, N. S., \& Abadi, T. (2017). Kajian Neraca Air Kawasan Akibat Pengambilan Air Bawah Tanah Oleh Sektor Pertanian. Jurnal Rekayasa Infrastruktur Hexagon, 2(1).

Fakhrudin, M., Wibowo, H., Subehi, L., \& Ridwansyah, I. (2002). Karakterisasi Hidrologi Danau Maninjau Sumatera Barat. Menuju Kesinambungan Pemanfaatan Sumberdaya Perairan, April.

Ferdiansyah, A., Yuningsih, S. M., Ginanjar, M. R., \& Akrom, I. F. (2020). Potensi Debit Aliran Lokal Waduk Saguling Menggunakan Model Hujan Limpasan. JURNAL SUMBER DAYA AIR, 16(1). https://doi.org/10.32679/jsda.v16i1.606

Indarto. (2010). Dasar Teori dan Contoh Aplikasi Model Hidrologi. Bumi Aksara.

Isfaudin, I., \& Mandaka, M. (2020). Kawasan Wisata Telaga Menjer di Wonosobo dengan Pendekatan Arsitektur Vernakular. Journal of Architecture, 6(1).

Listyarini, D., Hidayat, Y., \& Tjahjono, B. (2018). MITIGASI BANJIR DAS CITARUM HULU BERBASIS MODEL HEC-HMS. Jurnal Ilmu Tanah Dan Lingkungan, 20(1). https://doi.org/10.29244/jitl.20.1.40-48

Ma, Z. zhong, Ray, R. L., \& He, Y. ping. (2018). Assessing the spatiotemporal distributions of evapotranspiration in the Three Gorges Reservoir Region of China using remote sensing data. Journal of Mountain Science, 15(12). https://doi.org/10.1007/s11629-018-5180-2

Mokobombang, M. E., Sumarauw, J. S. F., \& Tanudjaja, L. (2016). Analisis Neraca Air Sungai Kinali Di Titik Bendung Kinali Ongkag Kabupaten Bolaang Mongondow. Jurnal Sipil Statik, 4(12).
Naharuddin, Harijanto, H., \& Wahid, A. (2018). Pengelolaan Daerah Airan Sungai Dan Aplikasinya Dalam Proses Belajar Mengajar (Pertama). Untad Press.

Piranti, A. S., Wibowo, D. N., \& Rahayu, D. R. U. S. (2021). Nutrient Determinant Factor of Causing Algal Bloom in Tropical Lake (Case Study in Telaga Menjer Wonosobo Indonesia). Journal of Ecological Engineering, 22(5), 156-165. https://doi.org/10.12911/22998993/135863

Ri, T., Jiang, J., Sivakumar, B., \& Pang, T. (2019). A statistical-distributed model of average annual runoff forwater resources assessment in DPR Korea. Water (Switzerland), 11(5). https://doi.org/10.3390/w11050965

Scharffenberg, W. (2016). Hydrologic Modelling System HEC-HMS Technical Reference Manual.

Soeprobowati, T. R. (2012). Peta Batimetri Danau Rawapening. Bioma : Berkala Ilmiah Biologi, 14(2). https://doi.org/10.14710/bioma.14.2.78-84

Supangat, A. B. (2016). Analisis perubahan nilai pendugaan evapotranspirasi potensial akibat perubahan iklim di kawasan hutan tanaman eucalyptus pellita. Seminar Nasional Geografi UMS 2016.

Syahputra, I. (2015). KAJIAN HIDROLOGI DAN ANALISA KAPASITAS TAMPANG SUNGAI KRUENG LANGSA BERBASIS HEC-HMS DAN HEC-RAS. Jurnal Teknik Sipil Unaya, 1(1). https://doi.org/10.30601/jtsu.v1i1.2

Triatmodjo, B. (2013). Hidrologi Terapan (ketiga). Beta Offset.

Tuo, Y., Duan, Z., Disse, M., \& Chiogna, G. (2016). Evaluation of precipitation input for SWAT modeling in Alpine catchment: A case study in the Adige river basin (Italy). Science of the Total Environment, 573, 66-82. https://doi.org/10.1016/j.scitotenv.2016.08.034

Wulandari, D. A., Budieny, H., \& Kurniani, D. (2016). Keakuratan Prediksi Inflow Waduk Dengan Neraca Air Waduk. Teknik, 37(2). https://doi.org/10.14710/teknik.v37i2.12613

Zulaeha, S., Nur Faridah, S., Achmad, M., \& Mubarak, H. (2020). Prediksi Debit Aliran Sub-DAS Bantimurung Menggunakan Model HEC-HMS. Jurnal Agritechno. 